\title{
ANALISIS PENERAPAN PMK NOMOR 31/PMK.07/2005 TENTANG TATA CARA PENGAJUAN USUL, PENELITIAN, DAN PENETAPAN PENGHAPUSAN PIUTANG DI RSUP PROF Dr. R. D. KANDOU MANADO
}

\author{
Calvien Kawenas ${ }^{1}$, Sifrid S. Pangemanan ${ }^{2}$, Robert Lambey ${ }^{3}$ \\ ${ }^{12}$ Fakultas Ekonomi dan Bisnis,Jurusan Akuntansi, Universitas Sam Ratulangi, Jl.Kampus Bahu, Manado, \\ 95115, Indonesia \\ E-mail : ckawenas10@gmail.com
}

\begin{abstract}
The write-off of receivables is a loss arising from uncollectible receivables caused by various causes. The problem raised in this study is whether the application procedure is in accordance with the PMK No. 31 / PMK.07 / 2005 and what factors become obstacles in the process of write-off of receivables. The method used in this research is descriptive research method that is qualitative. Based on the results of the research from the RSUP Prof. Dr. R. D. Kandou Manado, the procedures for the elimination of goods are in accordance with applicable government regulations. If the factors are negative inhibitors, the operational costs are irregular, the amount of operational costs required for the cost exceeds the amount of the receivables to be collected, the non-timeframe for submission of proposals for write-off of receivables, documents / filing requirements for origination submissions not made RSUP Prof. Dr. R. D. Kandou Manado must meet the requirements regarding the time period for collection of accounts more effective and efficient.
\end{abstract}

Keywords: Proposal Submission, Research, Accounts Receivable Removal

\section{PENDAHULUAN}

Rumah Sakit Pemerintah merupakan pelaksana teknis Kementerian Kesehatan RI yang diberi tugas dan wewenang untuk menyelenggarakan kegiatan jasa layanan, pendidikan, penelitian dan pengembangan serta usaha lain dalam bidang kesehatan yang bertujuan untuk meningkatkan derajat kesehatan dan senantiasa berorientasi kepada kepentingan masyarakat. Dalam upaya mewujudkan pelayanan kesehatan yang optimal dan bermutu, peranan Rumah Sakit menjadi sangat penting. Kekayaan Rumah Sakit merupakan kekayaan negara, yang tentu saja dikelola dan dimanfaatkan sepenuhnya untuk membiayai kegiatan operasional. Untuk mendukung kegiatan operasional, Rumah Sakit diberi kewenangan untuk memungut imbal jasa atas jasa layanan yang telah diberikan oleh Rumah Sakit, melakukan penangguhan pembayaran, maupun memberikan pembebasan sebagian atau seluruhnya terhadap biaya pasien/jasa layanan yang telah diberikan dan Piutang lainnya. Instansi Pemerintah, dalam hal ini Rumah Sakit lebih mengutamakan kepentingan atau kepedulian sosial dibandingkan keuntungan. Akuntansi Rumah Sakit yang merupakan salah satu kegiatan dari keuangan dan administrasi umum adalah salah satu sasaran yang harus diperbaiki agar dapat memberikan data dan informasi yang akan mendukung para direktur Rumah Sakit dalam pengambilan keputusan maupun pengamatan serta pengendalian kegiatan Rumah Sakit. Salah satu yang ditangani akuntansi adalah piutang. Piutang merupakan salah satu sumber pendapatan dan dapat meningkatkan penghasilan untuk Rumah Sakit, namun ketika jumlah piutang tak tertagih jumlahnya tinggi, maka akan menghambat kegiatan operasional Rumah Sakit. Piutang menunjukkan adanya klaim perusahaan kepada pihak lain akibat kejadian di waktu sebelumnya dalam bentuk uang, barang, jasa atau dalam bentuk aktiva non kas lainnya yang harus dilakukan penagihan (collect) pada tanggal jatuh temponya. Piutang merupakan salah satu jenis aktiva lancar, sejumlah investasi perusahaan sebagian besar terdapat pada piutang. 
Pos piutang timbul karena terjadinya suatu transaksi secara kredit, karena itu pembayaran dan pelunasan sangat erat sekali dengan jangka waktu tertentu (Liska, Suhardi M, 2013). Piutang juga menimbulkan risiko yang cukup besar, dimana akan terjadi keterlambatan dalam pelunasan dan kemungkinan tidak tertagihnya sebagian bahkan seluruhnya sehingga menimbulkan penghapusan piutang. Penghapusan piutang adalah suatu kerugian yang timbul karena adanya piutang yang tidak tertagih. Piutang kurang terjamin pelunasannya, karena tidak dibuat dalam suatu perjanjian khusus seperti yang diatur oleh peraturan hukum, oleh sebab itu, maka piutang inilah yang biasanya mengandung penghapusan piutang. Dalam melakukan penghapusan piutang Rumah Sakit, juga diperlukan beberapa langkah awal sesuai dengan Peraturan Menteri Keuangan RI yang berlaku, yaitu melakukan penelitian awal yang dilakukan oleh pihak Rumah Sakit, kemudian rimah sakit melakukan pengajuan usul penghapusan piutang ke Kantor Pelayanan Kekayaan Negara dan Lelang, kemudian Kantor Pelayanan Kekayaan Negara dan Lelang melakukan penelitian terkait dengan dokumendokumen piutang yang diserahkan oleh pihak Rumah Sakit untuk dihapuskan, sebelum pihak Rumah Sakit menetapkan penghapusan piutang. Tetapi, yang terjadi di RSUP Prof. Dr. R. D. Kandou Manado, dokumen-dokumen untuk melakukan atau menetapkan penghapusan piutang, yaitu dokumen pengajuan usul baru diusulkan untuk dilakukan penghapusan piutang hingga saat ini baru sampai dengan tahun 2008, sedangkan dokumen pengajuan usul dari tahun 2009-2016 masih belum diusulkan karena terhambat kelengkapan persyaratan pengajuan usul untuk melakukan penghapusan piutang. Kendala-kendala yang didapati dalam proses penghapusan piutang Rumah Sakit diantaranya adalah kurangnya usaha penagihan yang dilakukan dan tudak diaturnya jangka waktu penyerahan pengajuan usul untuk melakukan penghapusan piutang. Mengingat pentingnya pengelolaan piutang di Rumah Sakit, khususnya dalam proses melakukan penetapan penghapusan piutang maka Rumah Sakit harus melakukan langkah yang kongkrit agar proses ini tidak tertahan lama dan menjadi penghambat dalam kemajuan Rumah Sakit. Berdasarkan latar belakang, maka tujuan dari penelitian ini adalah untuk mengetahui tata cara penetapan penghapusan piutang di RSUP Prof Dr. R. D. Kandou Manado sudah sesuai dengan Peraturan Menteri Keuangan yang berlaku dan untuk mengetahui kendala-kendala yang dihadapi RSUP Prof Dr. R. D. Kandou Manado sehingga pengajuan usul untuk menetapkan penghapusan piutang tertahan lama serta memberikan solusinya.

\section{TINJAUAN PUSTAKA}

\subsection{Akuntansi Keuangan}

Donald E. Kieso (2013: 4) akuntansi keuangan merupakan proses yang berujung pada penyusunan laporan keuangan perusahaan untuk digunakan oleh pihak internal maupun eksternal. Martani (2012: 8) akuntansi keuangan berorientasi pada pelaporan pihak eksternal. Beragamnya pihak eksternal dengan tujuan spesifik bagi masing-masing pihak membuat pihak penyusun laporan keuangan menggunakan prinsip dan asumsi-asumsi dalam penyusunan laporan keuangan. Untuk itu diperlukan standar akuntansi yang dijadikan pedoman baik oleh penyusun maupun oleh pembaca laporan keuangan. Laporan yang dihasilkan dari akuntansi keuangan berupa laporan keuangan untuk tujuan umum.

\subsection{Konsep Piutang}

Piutang adalah jumlah tagihan dari perusahaan terhadap pelanggan berdasarkan penjualan kredit yang telah dilakukan sebelumnya (Manurung, 2011: 67). Piutang merupakan aset perusahaan atau entitas lainnya yang timbul karena terjadinya transaksi penjualan barang atau jasa secara kredit yang dihasilkan oleh perusahaan (Rendy, 2014). Secara umum piutang diartikan sebagai klaim atas uang penerimaan pembayaran yang dimiliki oleh seseorang atau badan lain yang disebut kreditur, akan tetapi berdasarkan asal 
usul piutang dapat diartikan sebagai suatu tuntutan atau tagihan hasil penjualan barang dagangan atau jasa menjadi suatu usaha pokok perusahaan kepada pembelinya dimana pembayarannya akan terjadi pada saat jatuh tempo (Astria Dwi Pujiati, 2014).

Ahmad Syakur (2014: 105) menyatakan manajemen piutang yang efektif sangat diperlukan agar tidak terjadi kerugian akibat adanya piutang yang tidak dapat ditagih dan kerugian yang timbul akibat penyalahgunaan piutang oleh karyawan. Kerugian ekonomis yang diakibatkan oleh adanya piutang yang tidak dapat ditagih atau penyalahgunaan piutang oleh karyawan tidah hanya sebesar nilai nominal piutang tersebut, melainkan juga meliputi keruguan akibat hilangnya kesempatan untuk memperoleh pendapatan (opportunity cost) sebesar tingkat laba investasi dari piutang yang tidak dapat ditagih. Sedangkan kerugian ekonomis yang timbul akibat keterlambatan penerimaan piutang hanya meliputi kerugian atas hilangnya kesempatan untuk memperoleh pendapatan dari pemanfaatan ekonomis dari piutang tersebut.

Piutang Tak Tertagih (uncollectible account) merupakan Piutang debitur bermasalah yang tidak dapat melunasi utang-utangnya (Hayuningtyas Pramesti Dewi, 2014). Dari sekian banyak debitor perusahaan mungkin ada diantaranya debitor yang mungkin tidak dapat memenuhi kewajiban untuk membayar hutang-hutangnya kepada perusahaan, misalnya debitor yang dinyatakan pailit oleh pengadilan. Piutang kepada debitor yang bermasalah demikian ini yang kemudian dinyatakan sebagai piutang tidak dapat ditagih (Ahmad Syakur, 2014: 106). Piutang lain-lain merupakan klaim kepada pihak ketiga yang timbul karena kejadian di masa lalu yang tidak terkait dengan kejadian penyerahan barang atau jasa yang diperdagangkan atau diproduksi. Perputaran piutang adalah periode terikatnya piutang yang menunjukkan berapa kali piutang tersebut berputar selama periode tertentu sejak terjadinya piutang sampai piutang tertagih kembali kedalam kas perusahaan (Luh Komang Suamami, Suwandra I Wawan, Wayan Cipta, 2014).

\subsection{Konsep Penghapusan Piutang}

Pengajuan usul penghapusan piutang diusulkan oleh pihak direksi perusahaan negara kepada Kementerian Keuangan. Usul penghapusan piutang disampaikan secara tertulis dilampiri dengan dokumen-dokumen persyaratan, diantaranya daftar normatif penanggung utang, surat keputusan/berita acara, dan surat pernyataan PSBDT dari PUPN Cabang. Penelitian dilakukan untuk mengetahui bahwa kelengkapan persyaratan telah terpenuhi dan dapat dibuktikan kebenarannya. Dalam hal dari hasil penelitian tidak terpenuhi dan/atau tidak dapat dibuktikan kebenarannya, usul penghapusan piutang tidak dapat diterima.

Penghapusan Piutang adalah suatu kerugian yang timbul karena adanya piutang yang tidak tertagih. Piutang kurang terjamin pelunasannya, karena tidak dibuat dalam suatu perjanjian khusus seperti yang diatur oleh peraturan hukum. Oleh sebab itu, maka piutang inilah yang biasanya mengandung penghapusan piutang. Adakalanya telah dapat dipastikan bahwa piutang kepada seorang pelanggan tertentu tidak akan dapat ditagih. Sebabnya macam-macam, yaitu karena pelanggan yang bersangkutan telah dinyatakan pailit, bangkrut, meninggal dunia, atau lari ke luar negeri. Untuk itu membukukan penghapusan piutang, dikenal dua metode, yaitu:

1. Metode Langsung (Direct Write Off Method) Menurut metode ini, pembukuan penghapusan piutang baru akan dilakukan pada saat suatu piutang benar-benar dinyatakan tidak tertagih oleh perusahaan. Pada saat itulah diadakan pencatatan kerugian tersebut kedalam perkiraan penghapusan piutang disebalah debit, serta mengkreditkan perkiraaan piutang dalam jumlah yang sama, guna mengeluarkan piutang yang tidak tertagih itu dari catatan. Dalam metode ini, setiap piutang yang sudah diputuskan untuk dihapuskan, langsung dibebankan sebelah debet "beban penghapusan piutang" dan sebelah kredit "piutang". Pencatatan kerugian piutang 
diakui dan dicatat ketika debitur sudah tidak mungkin lagi membayar utangnya, sehingga jurnalnya:

Beban Penghapusan Piutang

Piutang

Rp XXX

$\operatorname{Rp} X X X$

Andaikata suatu saat tiba-tiba debitur memberi tahu bahwa akan melakukan pelunasan pembayaran, maka jurnalnya:

Piutang Rp XXX

Beban Penghapusan Piutang Rp XXX

Selanjutnya apabila diterima pelunasan piutang maka jurnalnya:

Kas

Rp XXX

Piutang

Rp XXX

2. Metode Cadangan (Allowance Method) Menurut metode ini, setiap akhir periode perusahaan perlu mengadakan penaksiran tentang besarnya piutang yang kira-kira tidak tertagih. Pada saat ini jumlah yang diperkirakan tidak tertagih tersebut dianggap dan dicatat sebagi kerugian, dengan cara mendebitkannya kedalam perkiraan penghapusan piutang. Tetapi pada saat ini jumlah piutang yang diduga tidak tertagih tersebut belum dikeluarkan dari perkiraan piutang, melainkan baru dianggap dan dicatat sebagai cadangan piutang yang sekiranya tidak tertagih. Pencadangan ini dilakukan dengan membukukannya ke dalam perkiraan cadangan penghapusan piutang (Allowance For Bad Debt) disebelah kredit. Bilamana pada sesuatu waktu nanti, piutang yang dicadangkan tidak tertagih itu benar-benar dinyatakan tidak tertagih, maka jumlah tersebut harus dikeluarkan dari catatan perkiraan cadangan penghapusan piutang, karena status cadangan telah berubah menjadi suatu kepastian, yakni dipastikan tidak tertagih lagi. Dengan demikian perkiraan cadangan penghapusan piutang harus didebitkan sebesar piutang yang dinytakan tidak tertagih tersebut. Di samping itu, dengan dipastikannya bahwa piutang yang bersangkutan tidak akan tertagih, maka jumlah tersebut harus pula dikeluarkan dari catatan perkiraan piutang, dengan cara mengkreditkannya sebesar jumlah tersebut. Bila pengahapusan piutang tak tertagih naik maka nilai piutang akan berkurang, sebaliknya jika penghapusan tak tertagih turun maka nilai piutang akan naik, penghapusan piutang tak tertagih ini biasanya oleh pihak perusahaan ditetapkan persentase tertentu dari piutangnya. nilai piutang yang dihapusakan karena tidak tertagih, yang disajikan dalam neraca dipengaruhi oleh dua metode yaitu, metode penghapusan langsung dan metode penyisihan. Yang mungkin akan menghasilkan nilai piutang yang berbeda jika digunakan kedua metode tersebut. Dalam metode ini, pada setiap akhir periode akan dilakukan penaksiran terhadap piutang yang tidak lagi dapat tertagih, jurnalnya:

Beban Penghapusan Piutang Rp XXX

Penyisihan Penghapusan Piutang Rp XXX

\section{METODE PENELITIAN}

\subsection{Jenis Penelitian}

Penelitian ini merupakan jenis penelitian kualitatif deskriptif. Sadarmayanti \& Hidayat (2011: 33) penelitian deskriptif adalah suatu metode dalam pencarian fakta status sekelompok manusia, suatu objek, suatu kondisi, suatu sistem pemikiran ataupun suatu peristiwa pada masa sekarang dengan interpretasi yang tepat. Sedangkan menurut Suryabrata (2013: 75) penelitian deskriptif merupakan jenis penelitian yang tujuannya untuk membuat pecandraan secara sistematis, faktual, dan akurat mengenai fakta-fakta dan sifat-sifat populasi atau daerah tertentu. Penelitian yang akan dilakukan penulis merupakan penelitian kualitatif deskriptif yaitu suatu penelitian yang digunakan untuk menganalisa penerapan Peraturan Menteri Keuangan Republik Indonesia Nomor 31/PMK.07/2005 tentang Tata Cara Pengajuan 
Usul, Penelitian, dan Penetapan Penghapusan Piutang di RSUP Prof. Dr. R. D. Kandou Manado.

\subsection{Tempat dan Waktu Penelitian}

Penelitian akan dilakukan di RSUP Prof. Dr. R. D. Kandou Manado sebagai instansi yang dianggap berkaitan dengan data yang dibutuhkan. Waktu penelitian dilaksanakan selama 5 bulan yaitu Desember 2016 sampai dengan April 2017.

\subsection{Prosedur Penelitian}

Penulis melakukan identifikasi terhadap masalah yang hendak diteliti dan mencari informasi pendukung untuk menguatkan judul yang dipilih. Selanjutnya peneliti mentukan objek yang akan digunakan. Setelah penentuan objek penelitian, langkah selanjutnya adalah mengumpulkan data yang terkait dengan penelitian ini. Pengumpulan data dilakukan dengan mewawancarai kepala sub bagian mobilisasi dana RSUP Prof Dr. R. D. Kandou Manado yang bertugas untuk mengatur keuangan termasuk yang berhubungan dengan penghapusan piutang dan pihak yang terkait dalam penelitian ini sesuai dengan tugasnya masing-masing, serta mengumpulkan bukti-bukti mengenai tata cara pengajuan usul, penelitian, dan penetapan penghapusan piutang. Setelah memperoleh data-data, peneliti melakukan analisis dan mengolah data-data yang ada sesuai dengan rumusan masalah yang telah ditentukan sebelumnya. Peneliti kemudian membandingkan data hasil penelitian dengan Peraturan Menteri Keuangan Republik Indonesia. Hal-hal yang menjadi perbandingan yaitu tata cara pengajuan usul, penelitian, dan penetapan penghapusan piutang. Tata cara pengajuan usul, penelitian, dan penetapan penghapusan piutang di RSUP Prof Dr. R. D. Kandou Manado memberikan hasil penelitian yang nantinya akan mengacu pada Peraturan Menteri Keuangan Republik Indonesia yang berlaku saat ini. Ini merupakan tahap akhir dari penelitian dalam hal ini penarikan kesimpulan dan pemberian saran atas apa yang telah diteliti.

\subsection{Metode Pengumpulan Data}

Penelitian ini menggunakan jenis data yang bersifat kualitatif dimana data yang disajikan dalam bentuk kata-kata atau uraian kalimat. Teknik pengumpulan data dalam penelitian ini yaitu teknik wawancara dan observasi karena penulis melakukan wawancara langsung dengan pihak-pihak yang terkait dengan judul penelitian dan melakukan pengumpuan data tentang tata cara pengajuan usul, penelitian, dan penetapan penghapusan piutang.

\section{5. $\quad$ Metode Analisis}

Metode analisis data yang dilakukan adalah metode deskriptif yang bersifat kualitatif yaitu suatu metode yang dilakukan dengan cara mengumpulkan, menyajikan, serta menganalisis data dan menguraikannya dengan kalimat sehingga diperoleh gambaran yang cukup jelas tentang masalah yang dihadapi, kemudian ditarik suatu kesimpulan mengenai analisis penerapan tata cara pengajuan usul, penelitian, dan penetapan penghapusan piutang apakah sesuai dengan Peraturan Menteri Keuangan Republik Indonesia yang berlaku.

\section{HASIL PENELITIAN DAN PEMBAHASAN}

\subsection{Hasil Penelitian}

\subsubsection{Prosedur Penetapan Piutang}

Petugas pengelola piutang menerima berkas biaya perawatan pasien/biaya layanan dari pusat pertanggungjawaban pendapatan, antara lain instalasi rawat darurat, instalasi rawat jalan, dan instalasi rawat inap atau unit yang mengelola pendapatan usaha lainnya dan 
pendapatan lainnya. Penetapan piutang oleh rumah sakit/balai, setelah adanya atau dipenuhinya syarat.

\subsubsection{Penatausahaan Piutang}

Penatausahaan piutang adalah proses pencatatan dan pelaporan jumlah uang yang menjadi hak Badan Layanan Umum atau kewajiban pihak lain kepada Badan Layanan Umum sebagai akibat penyerahan jasa, barang, dan kegiatan lainnya berdasarkan peraturan perundang-undangan yang berlaku.

\subsubsection{Tata Cara dan Kewenangan Penghapusan Piutang}

1. Penghapusan Bersyarat

Penghapusan piutang secara bersyarat dilakukan dengan cara sebagai berikut:

a. Dalam hal piutang BLU rumah sakit/balai tidak terselesaikan setelah dilakukan penagihan secara maksimal, BLU rumah sakit/balai menyerahkan pengurusan penagihan tersebut kepada Panitia Urusan Piutang Negara/Kantor Pelayanan Kekayaan Negara dan Lelang;

b. Penyerahan pengurusan piutang BLU rumah sakit/balai sebagaimana dimaksud pada butir a dilaksanakan sesuai ketentuan peraturan perundang-undangan di bidang pengurusan Piutang Negara;

c. Pengurusan Piutang BLU rumah sakit/balai sebagaimana dimaksud dalam butir b dilakukan oleh Panitia Urusan Piutang Negara/Kantor Pelayanan Kekayaan Negara dan Lelang sampai lunas, selesai atau optimal;

d. Pengurusan Piutang BLU rumah sakit/balai dinyatakan telah optimal, dalam hal telah dinyatakan sebagai PSBDT oleh Panitia Urusan Piutang Negara/Kantor Pelayanan Kekayaan Negara dan Lelang;

e. Terhadap Piutang BLU rumah sakit/balai yang telah dinyatakan PSBDT oleh Panitia Urusan Piutang Negara/Kantor Pelayanan Kekayaan Negara dan Lelang, Pemimpin BLU rumah sakit/balai melakukan penghapusan secara bersyarat terhadap Piutang BLU rumah sakit/balai dengan menerbitkan Surat keputusan penghapusan;

f. Format Surat keputusan penghapusan sebagaimana dimaksud pada butir e sesuai dengan lampiran PMK No.230/PMK.05/2009 tentang Penghapusan Piutang BLU;

g. Penghapusan secara bersyarat terhadap Piutang BLU rumah sakit/balai sebagaimana dimaksud pada butir e dilakukan dengan menghapuskan Piutang BLU rumah sakit/balai dari pembukuan BLU rumah sakit/balai tanpa menghapuskan hak tagih Negara;

h. Penghapusan Piutang BLU rumah sakit/balai sebagaimana dimaksud pada butir g dilengkapi:

1. Daftar nominatif para penanggung utang;

2. Besaran piutang yang dihapuskan; dan

3. Surat pernyataan PSBDT dari Panitia Urusan Piutang Negara/Kantor Pelayanan Kekayaan Negara dan Lelang.

Kewenangan penghapusan piutang secara bersyarat terhadap piutang BLU dilakukan dengan cara sebagai berikut:

1. Pemimpin BLU diberikan kewenangan penghapusan secara bersyarat sesuai jenjang kewenangannya;

2. Penghapusan secara bersyarat terhadap Piutang BLU baik perseorangan maupun jaminan ditetapkan oleh: 


\section{a. Pemimpin BLU untuk jumlah sampai dengan Rp. 200.000.000 (dua ratus juta rupiah) per penanggung utang; \\ b. Pemimpin BLU dengan persetujuan Dewan Pengawas untuk jumlah lebih dari Rp. 200.000.000 (dua ratus juta rupiah) sampai dengan Rp. 500.000.000 (lima ratus juta rupiah) per penanggung utang;}

3. Dalam hal tidak terdapat Dewan Pengawas, persetujuan sebagaimana dimaksud pada butir $2 \mathrm{~b}$ diberikan oleh pejabat yang ditunjuk oleh menteri/pimpinan lembaga yang bersangkutan;

4. Penghapusan secara bersyarat, sepanjang menyangkut piutang BLU rumah sakit/balai untuk jumlah lebih dari Rp. 500.000.000 (lima ratus juta rupiah) dilaksanakan sesuai ketentuan peraturan perundang-undangan di bidang penghapusan Piutang Negara;

5. Dalam hal piutang BLU rumah sakit/balai menggunakan satuan mata uang asing, nilai piutang yang dihapuskan secara bersyarat adalah nilai yang setara dengan nilai kurs tengah Bank Indonesia yang berlaku pada 3 (tiga) hari sebelum tanggal Surat pengajuan usul penghapusan oleh pejabat keuangan BLU rumah sakit/balai.

2. Penghapusan Mutlak

Penghapusan Piutang secara mutlak dilakukan sebagai berikut:

1. Penghapusan Piutang di BLU rumah sakit/balai dilakukan terhadap seluruh sisa piutang per debitur yang telah diterbitkan SK penghapusan piutang bersyarat;

2. Penghapusan Piutang sebagaimana dimaksud pada butir 1 , dilaksanakan sesuai ketentuan peraturan perundang-undangan;

3. Pengusulan Penghapusan Secara Mutlak atas Piutang BLU rumah sakit/balai diajukan setelah lewat waktu dua tahun sejak penetapan Penghapusan Secara Bersyarat dan disampaikan secara tertulis ke Direktur Jenderal Bina Upaya Kesehatan cq. Bagian Keuangan dengan dilampiri dokumen sekurangkurangnya: (PMK NO. 31/PMK.07/2005)

a. Daftar nominatif Penanggung Utang yang berisi rincian nama Penanggung Utang, nomor PSBDT, nilai piutang, dan Kantor Pelayanan Kekayaan Negara dan Lelang yang mengurusi;

b. Surat penetapan Penghapusan Secara Bersyarat atas piutang yang diusulkan untuk dihapuskan secara mutlak;

c. Surat keterangan dari Aparat/Pejabat yang berwenang menyatakan bahwa Penanggung Utang tidak mempunyai kemampuan untuk menyelesaikan sisa kewajibannya.

\subsubsection{Akuntansi dan Pelaporan Piutang}

A. Perlakuan Akuntansi

1. Pengakuan

a. Piutang pelayanan diakui pada saat seluruh kondisi berikut ini dipenuhi:

(1) jumlah piutang dapat diukur dengan andal yakni telah didukung dengan dokumen penetapan piutang (surat pernyataan utang, hasil verifikasi/berita acara, dsb) yang disepakati oleh pihak BLU rumah sakit/balai dan debitur (perorangan, perusahaan, dan penjamin);

(2) besar kemungkinan manfaat ekonomi sehubungan dengan transaksi tersebut akan diperoleh BLU rumah sakit/balai;

(3) tingkat penyelesaian dari suatu transaksi pada tanggal neraca dapat diukur dengan andal; dan 
(4) beban yang terjadi untuk transaksi dan untuk menyelesaikan transaksi tersebut dapat diukur dengan andal;

b. Piutang Usaha Lainnya diakui pada saat jasa telah diberikan kepada penerima;

c. Piutang Lainnya diakui pada saat timbulnya hak tagih kepada pihak yang berutang.

2. Pengukuran

Piutang diukur sebesar nilai bersih yang dapat direalisasikan.

3. Penyajian

a. Piutang disajikan pada kelompok pos aset lancar dalam Neraca;

b. Piutang disajikan dalam jumlah bruto dengan penyisihan piutang;

c. Piutang lain-lain yang jatuh tempo lebih dari satu tahun disajikan dalam kelompok pos aset non lancar.

4. Pengungkapan

Hal yang diungkapkan dalam Catatan atas Laporan Keuangan antara lain sebagai berikut:

a. Rincian jumlah dan jenis piutang;

b. Jumlah piutang dengan pihak-pihak yang memiliki hubungan istimewa;

c. Kualitas piutang dan jumlah penyisihan piutang berdasarkan klasifikasi kualitas piutang;

d. Kualitas piutang berdasarkan proses penagihan yang telah dilakukan atas saldo piutang yang disajikan dalam neraca;

e. Jumlah piutang yang diserahkan kepada Panitia Urusan Piutang Negara/Kantor Pelayanan Kekayaan Negara dan Lelang, Ditjen Kekayaan Negara Kementerian Keuangan.

B. Penyisihan Piutang

Penyisihan Piutang adalah jumlah yang disisihkan sebagai piutang tak tertagih menjadi unsur pengurang jumlah piutang dalam laporan keuangan, sehingga nilai piutang mencerminkan nilai yang dapat ditagih. Untuk kelengkapan informasi, jumlah piutang asal (nominal), jumlah penyisihan dan dasar penyisihannya dijelaskan dalam Catatan atas Laporan Keuangan (CaLK) Semester dan Tahunan.

C. Penilaian Kualitas Piutang

\begin{tabular}{|c|c|c|}
\hline NO & Kualitas Piutang & Umur Piutang \\
\hline 1 & Lancar & $0-4$ Bulan \\
\hline 2 & Kurang Lancar & $>4-8$ Bulan \\
\hline 3 & Diragukan & $>8-12$ Bulan \\
\hline 4 & Macet & $>12$ Bulan \\
\hline
\end{tabular}

D. Penyisihan Piutang Tak Tertagih

\begin{tabular}{|c|c|c|c|}
\hline NO & Kualitas Piutang & Umur Piutang & $\%$ Penyisihan Piutang \\
\hline 1 & Lancar & $0-4$ Bulan & $0,5 \%$ \\
\hline 2 & Kurang Lancar & $>4-8$ Bulan & $10 \%$ \\
\hline 3 & Diragukan & $>8-12$ Bulan & $50 \%$ \\
\hline 4 & Macet & $>12$ Bulan & $100 \%$ \\
\hline
\end{tabular}




\subsection{Pembahasan}

\subsubsection{Pengajuan Usul}

Berdasarkan penelitian yang sudah dilakukan, pelaksanaan pengajuan usul penghapusan piutang di RSUP Prof. Dr. R. D. Kandou Manado belum berjalan dengan baik, dikarenakan piutang yang seharusnya diusulkan untuk dihapuskan tertahan sangat lama, yakni piutang yang sudah macet sejak tahun 2009-2016 baru diusulkan untuk dihapus pada awal tahun 2017, sehingga masih ada piutang yang sudah dikategorikan sebagai piutang macet tetapi belum diserahkan ke Panitia Urusan Piutang Negara/Direktorat Jenderal Kekayaan Negara dalam hal ini Kantor Pelayanan Kekayaan Negara dan Lelang untuk segera dilakukan penghapusan piutang.

\subsubsection{Penelitian}

Berdasarkan penelitian yang sudah dilakukan, prosedur penelitian untuk dilakukannya penghapusan piutang di RSUP Prof. Dr. R. D. Kandou Manado belum berjalan dengan semestinya. Penelitin disini ada dua tahap, yaitu penelitian sebelum diajukan usul penghapusan piutang dan penelitian sesudah diajukan usul penghapusan piutang. Penelitian sebelum dilakukan pengajuan usul dilakukan oleh pihak rumah sakit, dimana pegawai yang bertugas melakukan survei ke tempat tinggal penanggung hutang, tetapi tidak berjalan dengan baik karena usaha penagihan yang dilakukan terkendala biaya operasional, seperti biaya transportasi dan akomodasi yang bisa saja lebih merugikan pihak rumah sakit, sehingga usaha penagihan yang dilakukan belum maksimal. Kendala lain yaitu pihak Rumah Sakit tidak menetapkan jangka waktu penyerahan dokumen penghapusan piutang, sehingga membuat karyawan bekerja tanpa tenggat waktu yang semestinya sudah harus ditentukan. Selanjutnya, penelitian dilakukan oleh Panitia Urusan Piutang Negara/Direktorat Jenderal Kekayaan Negara dalam hal ini Kantor Pelayanan Kekayaan Negara dan Lelang, untuk memastikan bahwa piutang yang diusulkan pihak rumah sakit untuk segera dihapuskan sudah benar-benar macet dan tidak lagi dapat ditagih.

\subsubsection{Penetapan Penghapusan Piutang}

Berdasarkan penelitian yang sudah dilakukan, RSUP Prof. Dr. R. D. Kandou Manado sudah menerapkan tata cara untuk melakukan penetapan penghapusan piutang sesuai dengan peraturan yang berlaku, dan tinggal menunggu keputusan dari Kementerian Keuangan melalui Panitia Urusan Piutang Negara/Direktorat Jenderal Kekayaan Negara dalam hal ini Kantor Pelayanan Kekayaan Negara dan Lelang.

\section{KESIMPULAN DAN SARAN}

\subsection{Kesimpulan}

Berdasarkan penelitian yang dilakukan dapat ditarik kesimpulan sebagai berikut:

1. RSUP Prof. Dr. R. D. Kandou Manado sudah melaksanakan setiap prosedur untuk melakukan penghapusan piutang sesuai dengan Peraturan Pemerintah yang berlaku. Hanya saja, meskipun RSUP Prof. Dr. R. D. Kandou Manado sudah melakukan tahapan yang sesuai dengan prosedur, masih ada kendala teknis yang menyebabkan prosedur tersebut belum berjalan dengan maksimal sehingga masih ada piutang yang sudah dikategorikan sebagai piutang macet tetapi belum diserahkan ke PUPN/DJKN dalam hal ini KPKNL untuk segera dilakukan penghapusan piutang.

2. Masih ada banyak hambatan yang dihadapi pihak rumah sakit, diantaranya yaitu surat penagihan piutang ke penanggung hutang yang masih dalam tahap SP 1 dan SP 2, belum sampai pada SP 3, tidak diaturnya jangka waktu penyerahan pengajuan usul untuk penghapusan piutang, dan resume penghapusan piutang per 
debitur yang belum dibuat sehingga pengajuan usul untuk melakukan penetapan penghapusan piutang ke PUPN/DJKN dalam hal ini KPKNL belum berjalan dengan baik.

\subsection{Saran}

Rumah sakit harus menetapkan aturan yang jelas agar tata cara penghapusan piutang bisa berjalan dengan baik. Contohnya mengenai pengajuan usul penghapusan piutang yang memiliki banyak hambatan. Rumah sakit harus mampu mengatasi permasalahanpermasalahan yang ada sehingga pengajuan usul untuk melakukan penghapusan piutang tidak tertahan lama dan bisa teratasi dengan baik. Diantaranya rumah sakit harus tegas menetapkan jangka waktu penagihan dari SP 1 sampai SP 3 sehingga proses penghapusan piutang tidak tertahan terlalu lama, kemudian dari pihak internal rumah sakit juga harus membuat sistem penagihan yang lebih efektif dan efisien, agar pegawai yang bertugas bisa melakukan usahausaha penagihan yang lebih maksimal, supaya rumah sakit juga tidak mengalami kerugian dikarenakan piutang yang tidak tertagih.

\section{DAFTAR PUSTAKA}

Ahmad Syakur. 2014. Intermediete Accounting, Jakarta: Pembuka Cakrawala.

Astria, Dwi Pujiati. 2014. Pengaruh Perputaran Piutang dan Perputaran Kas Terhadap Tingkat Likuiditas. Jurnal Ilmu \& Riset Akuntansi STIESIA Surabaya. Vol. 3 no. 7 (2014).

Dirjen Bina Upaya Kesehatan Kemenkes RI. 2014. Pedoman Piutang Badan Layanan Umum.

Donald E. Kieso. 2013. Akuntansi Intermediate Edisi Ke Lima Belas Jilid 1, Jakarta: Erlangga.

Dwi Martani, dkk. 2012. Akuntansi Keuangan Manengah Berbasis PSAK, Buku 1, Jakarta: Salemba Empat

Hayuningtyas, Pramesti Dewi. 2014. Analisis Sistem Pengendalian Internal Piutang Dalam Rangka Meminimalisasi Piutang Tak Tertagih Pada PT. Tucan Pumpco Services Indonesia. Jurnal STIE Trisakti.

Liska, Suhardi M. 2013. Peranan Internal Audit Terhadap Perencanaan dan Pengendalian Piutang Pada PT. Hadji Kalla Cabang Palopo. Jurnal Equilibrium. Vol. 3 No. 22013.

Luh, Komang Suamami, Suwandra, I Wawan, Wayan, Cipta. 2014. Pengaruh Perputaran Piutang dan Periode Pengumpulan Piutang Terhadap Profitasbilitas Pada Perusahaan Pembiayaan. E-journal Bisnis Universitas Pendidikan Ganesha. Vol. 2 Tahun 2014.

Manurung. 2011. Akuntansi Dasar (Untuk Pemula). Jakarta: PT Erlangga.

Sadarmayanti \& Hidayat. 2011. Metodologi Penelitian. Bandung: Mandar Maju.

Suryabrata. 2013. Metodologi Penelitian. Jakarta Utara: PT Raja Grafindo Persada. 